Maja Jandrić ${ }^{\star}$

University of Belgrade, Faculty of Economics, Serbia

\title{
Measures of de facto employment protection legislation
}

DOI: 10.7595/management.fon.2019.0008

Abstract:

Research Question: The aim of this paper is to construct a numerical measure of EPL which takes into consideration the implementation of legislation and employment structure. Motivation: It is recognized in the literature that in countries with a significant share of the shadow economy the labour market flexibility is de facto higher than the original EPL index based on de iure conditions implies. Since the sub-index which refers to the workers with permanent contracts has the largest weight in the EPL index calculation, taking into consideration the share of workers with regular contracts in total employment would give a clearer picture about the real influence of individual sub-indices. Idea: For international comparisons of de iure strictness of the employment protection legislation, we use the latest official OECD data on EPL index and its sub-indices. The OECD data for Serbia shows only the values for EPR, EPC and EPRC sub-indices. After calculation of EPT sub-index and EPL index for Serbia, three adjusted indices are developed in order to capture the effective (i.e., de facto) strictness of the employment protection legislation in different countries. Data: The analysis was based on the latest available official OECD data on the EPL indices (2012 to 2015, depending on a country). For the calculation of missing sub-indices for Serbia, the main source of information was the Labour Law. Data on shadow economy are based on Krstic et al. (2013) and Schneider (2016), while the data regarding employment structure stem from Labour Force Surveys. Tools: Calculation of EPT and EPL indices was conducted in accordance with the official OECD methodology for calculating summary indicators of EPL strictness. The methodology for calculation of adjusted indices is developed on the initial basis of the previous research from Berger et al. (2016), Eamets \& Paas (2007a), Boeri \& van Ours (2008), Rutkowski \& Scarpetta (2005) and Jandric (2014). Findings: The analysis was performed for 26 European countries. Rankings of European countries according to de facto strictness of the employment protection legislation differ significantly from the rankings made upon de iure strictness of the EPL. De facto external numerical flexibility of the labour market in Serbia is higher than when measured by the original unadjusted indices. Contribution: The main contribution of the paper is the development of the method for international comparisons of EPL, which provides a way to distinguish between de facto and de iure rigidity of employment protection legislation.

Key words: employment protection legislation, shadow economy, EPL index, labour market flexibility, labour law

JEL classification: K31, J80

\section{Introduction - Employment Protection Legislation Measurement}

The flexibility of the labour market can be viewed from numerous aspects: wage flexibility, functional flexibility, internal numerical and external numerical flexibility, geographical and occupational mobility or adaptability of knowledge and skills (Figure 1). External numerical flexibility refers to limits and ability of firms to hire and dismiss workers. Employment protection legislation (EPL) refers to the legal norms and procedures which regulate this field (Arandarenko, 2011a, p: 163). One of the main goals of the EPL is to ensure security for workers, particularly in case of redundancy (Amine, 2015). The main source of employment protection regulations is the Labour Law, but these rules can also be defined in collective agreements and individual labour contracts. EPL is one of the important elements of the labour market flexibility on the macroeconomic level.

Numerical measurement of employment protection legislation is a relatively complex task, due to a large number of legal norms that are often difficult to express numerically. In order to provide a numerical measurement of employment protection legislation, OECD has defined EPL index and accompanying sub-in- 
dices. Calculation of the EPL index is based on 21 basic items that refer to: a) protection of regular (permanent) workers against individual and collective dismissal and b) regulation of temporary forms of employment. In line with that, the aggregate EPL index consists of three main sub-indicators: 1) sub-index for the regular (permanent) contracts when individual dismissals are concerned (EPR), 2) sub-index which relates to the additional limitations for collective dismissals (EPC) and 3) sub-index for temporary contracts (EPT). EPRC is a sub-index which is also quite often used and refers to the protection of permanent workers against individual and collective dismissals. It represents the weighted average of EPR and EPC sub-indices. The EPL index and other sub-indices take values from 0 to 6 , where higher scores indicate stricter regimes. For more details on EPL index construction, see Appendix.

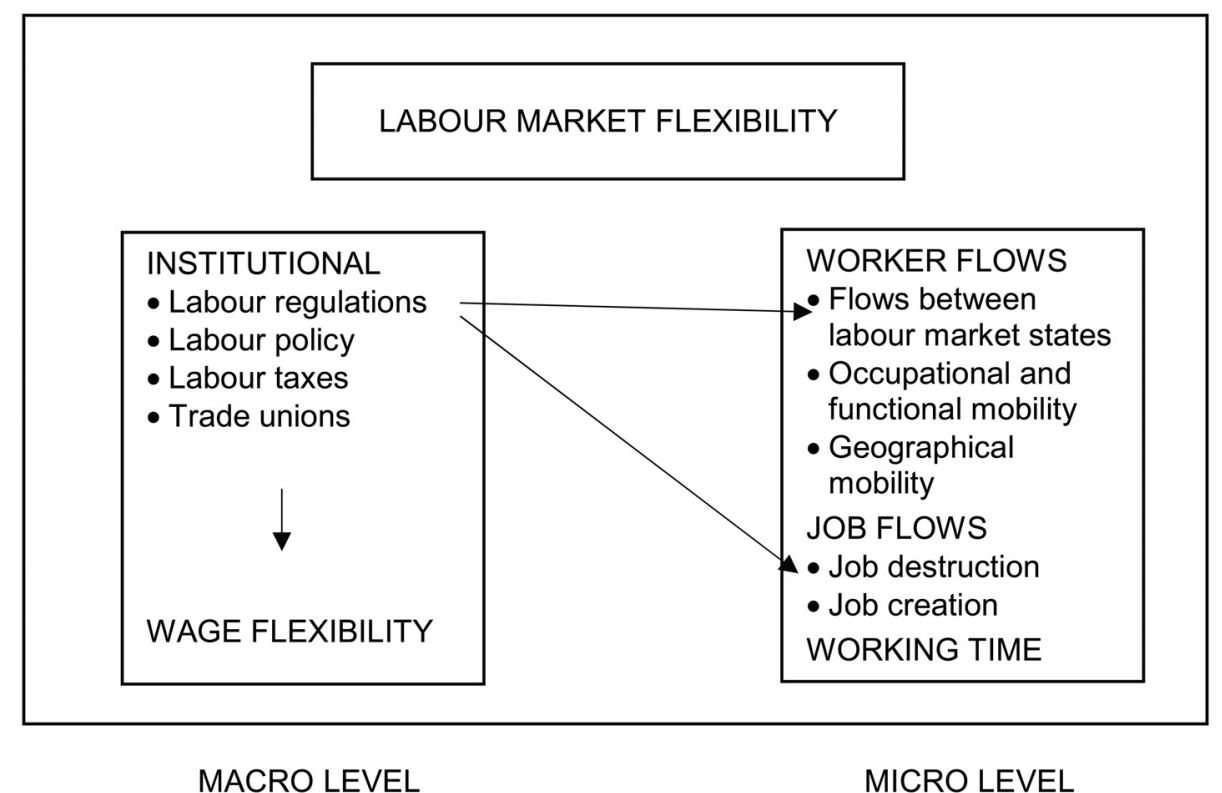

Figure 1: The elements of the labour market flexibility (Eamets \& Paas, 2007b, p. 6)

The use of this index is associated with some shortcomings:

- Legal provisions refer only to employees in the formal sector of the economy. In the countries having a significant share of the shadow economy, the labour market flexibility in this sense is de facto higher than the EPL index indicates.

- In many countries, certain groups of companies or employees, or even economy sectors, are exempted from EPL provisions or they are susceptible to certain changed legal provisions. These are mostly: small firms, participants in active labour market policies, apprentices or workers undertaking training, older workers, disabled persons, etc. (Venn, 2009). EPL often does not cover or it just partially covers certain forms of employment. e.g., self-employed and seasonal employees. EPL coverage varies significantly across countries and a "failure to account for it may lead to overestimating the importance of EPL, with this overestimation being especially large in lower-income countries" (Aleksynska \& Eberlein, 2016).

- Not all changes in employment protection legislation are reflected in the change of the EPL index. This can be caused by either a small change in legislation that is insufficient to modify the numerical scores which are the basis of the calculation of the EPL index, or by the fact that some aspects of the legislation are not taken into account in the calculation of the index (European Commision, 2016, p. 37).

- Certain aspects regarding the implementation of the legal norms are not included in the index. If the application of the legal norms is inadequate, the indicators which are based on the legal provisions do not give the real picture of the general employment protection legislation, which was especially noticeable during the transition process (Table 1). Myant \& Brandhuber (2016, p. 11) state that variation in labour law enforcement is an important issue, since the "abuses of employment law, at least in some countries, are widespread, making formal legal protections of questionable value to substantial parts of their labour forces". According to Verkerke \& Benoit (2017), some of the limitations of these indices refer to the insufficiency of practical information about enforcement, coverage and ease of law avoidance, with the additional problem being the implicit assumption that EPL applies to the whole labour market.

EPL covers only formal workers whose labour is observed by the state (World Bank, 2018). Although EPL is one of the possible triggers to higher informal economy (Fialova \& Schneider, 2014; Arsic, Arandarenko, Radulovic, Randjelovic, \& Jankovic, 2015), other authors emphasize that when enforcement of labour pro- 
tection policies is reasonably strict, employers have incentives to employ workers formally so as not to face penalties (Florez \& Perales, 2016). On the other hand, Djankov \& Ramalho (2009) state that developing countries with rigid labour regulation tend to have larger informal sectors, while the results of Ulyssea (2010) indicate that increasing the enforcement of labour regulations can be effective in reducing the size of the informal economy. Results from enterprise surveys indicate that EPL is not necessarily the main cause of informality, "not because the laws and regulations are irrelevant, but because they are regarded with irreverence" (World Bank, 2012).

EPL covers only formal workers whose labour is observed by the state (World Bank, 2018). Although EPL is one of the possible triggers to higher informal economy (Fialova \& Schneider, 2014; Arsic, Arandarenko, Radulovic, Randjelovic, \& Jankovic, 2015), other authors emphasize that when enforcement of labour protection policies is reasonably strict, employers have incentives to employ workers formally so as not to face penalties (Florez \& Perales, 2016). On the other hand, Djankov \& Ramalho (2009) state that developing countries with rigid labour regulation tend to have larger informal sectors, while the results of Ulyssea (2010) indicate that increasing the enforcement of labour regulations can be effective in reducing the size of the informal economy. Results from enterprise surveys indicate that EPL is not necessarily the main cause of informality, "not because the laws and regulations are irrelevant, but because they are regarded with irreverence" (World Bank, 2012).

Table 1: Classification of the transition countries according to the strictness and the level of EPL application in 2005

\begin{tabular}{|l|l|l|l|}
\hline & \multicolumn{1}{|c|}{ Flexible EPL } & \multicolumn{1}{|c|}{ More restrictive EPL } & \multicolumn{1}{c|}{ Very rigid EPL } \\
\hline $\begin{array}{l}\text { Weaker } \\
\text { enforcement }\end{array}$ & $\begin{array}{l}\text { Albania, } \\
\text { Kazakhstan }\end{array}$ & $\begin{array}{l}\text { Armenia, Georgia, } \\
\text { Russia, Serbia, } \\
\text { Montenegro, } \\
\text { Turkey }\end{array}$ & $\begin{array}{l}\text { Azerbaijan, Belarus, } \\
\text { BiH, Kyrgyz Republic, } \\
\text { Moldova, Ukraine, } \\
\text { Uzbekistan }\end{array}$ \\
\hline $\begin{array}{l}\text { Intermediate } \\
\text { enforcement }\end{array}$ & Bulgaria & $\begin{array}{l}\text { Croatia, Macedonia, } \\
\text { Romania }\end{array}$ \\
\hline $\begin{array}{l}\text { Stronger } \\
\text { enforcement }\end{array}$ & $\begin{array}{l}\text { Czech Republic, } \\
\text { Estonia, Hungary, } \\
\text { Poland, Slovakia }\end{array}$ & $\begin{array}{l}\text { Latvia, Lithuania, } \\
\text { Slovenia }\end{array}$ & \\
\hline
\end{tabular}

Source: Rutkowski \& Scarpetta (2005), p. 37.

Enforcement of EPL seems to be a critical issue. Some studies show that results of the empirical research focused on economic consequences of labour regulation differ if de facto measures of EPL are used instead of de iure measures (Kanbur \& Ronconi, 2018, Calderon, Chong, \& Leon, 2007). According to Boeri, Helppie, \& Macis (2008), "differences in enforcement across countries are as important or perhaps more important than differences in the letter of the law". Even within the EU, in spite of the EU Directives on labour standards, there are important country differences in enforcement, that have been accentuated by EU enlargement and the impact of the economic crisis (Quinlan \& Sheldon, 2011). However, studies that use de facto variables are very rare. Caballero, Cowan, Engel, \& Micco (2013) use a "rule of law" variable in order to capture difference between de iure and de facto regulations. The degree of enforcement of the EPL in Rutkowski \& Scarpetta (2005) was measured by the size of the informal economy - the higher the informal economy, the weaker is the estimated degree of enforcement. Authors used data on the informal economy from Schneider \& Klinglmair (2004), complemented with different country studies.

In this paper, we use a similar approach: we modify the original EPL index by the share of informal economy in GDP, as an approximation of the degree of employment protection legislation enforcement.

A clearer picture about the real influence of certain sub-indices of the employment protection legislation can be obtained if we also take into consideration the share of workers with regular contracts in total employment, since the system of calculation of the EPL index is such that the sub-index EPRC which refers to the workers with permanent contracts has the largest weight: $7 / 12$, compared to 5/12 for EPT sub-index (OECD, 2013, p. 77). Berger et al. (2016) modify the EPL index by weighing the sub-indices for regular and temporary workers by their respective share in the labour market. A similar approach was developed by Eamets \& Paas (2007a) who weighted the values of the EPL index in the Baltic countries with the share of employed persons with regular contracts. In the Baltic countries, at the beginning of the 2000s, the EPL index was approximately at the same level, and even higher than the average of EU-15, and at the same time, contrary to the theoretical hypotheses and events in other countries with similar employment protection legislation, restructuring and high labour turnover occurred. One of the explanations that Eamets and Paas (2007a) 
suggested was that there was a possibility that, in spite of the existence of the legal solutions which provide employment protection legislation in accordance to the average of EU countries, these regulations were not adhered to completely, which in reality increased this type of flexibility of labour market. A similar situation is found in Brazil, where, in spite of the strict labour regulation, there was a surprisingly large level of flexibility, which might be the consequence of low enforcement (Almeida \& Carneiro, 2012). Besides, more recent studies have found that "non-application of labour law was asserted to be a major cause of precarious work in many countries", especially in the CEE and Mediterranean clusters (Prosser, 2016, p. 955).

The real influence of the employment protection legislation in countries which have a significant rate of noncompliance with the law is quite hard to capture, but it is certain that in such conditions the real value of EPL is lower. The aim of this paper is to find the ranks of the countries based on the indices adjusted to the share of the shadow economy and the share of employed with standard contracts.

\section{Methodology and Data}

For international comparison of employment protection legislation, we use the latest official OECD data on the EPL index and its sub-indices: EPR, EPC, EPRC and EPT (2012 to 2015, depending on the country data availability). However, the OECD data for Serbia show the values for EPR, EPC and EPRC indices, while the value of EPT sub-index is missing. Therefore, it is not possible to calculate the value of the overall EPL index.

According to the OECD methodology, the EPT index is calculated on the basis of the following items, presented in Table 2:

Table 2: Items for calculation of EPT sub-index

\begin{tabular}{|l|l|}
\hline 1. & Valid cases for use of fixed-term contracts (FTC); \\
\hline 2. & Maximum number of successive FTC; \\
\hline 3. & Maximum cumulated duration of successive FTC; \\
\hline 4. & Types of work for which TWA employment is legal; \\
\hline $\mathbf{5 .}$ & Restrictions on number of renewals; \\
\hline $\mathbf{6 .}$ & Maximum cumulated duration of TWA assignments; \\
\hline 7. & Does the set-up of a TWA require authorization or reporting obligations; \\
\hline $\mathbf{8 .}$ & $\begin{array}{l}\text { Do regulations ensure equal treatment of regular and agency workers at } \\
\text { the user firm. }\end{array}$ \\
\hline
\end{tabular}

The first three items refer to fixed-term contracts, while the other five refer to temporary agency work. In order to calculate the EPT index, numerical values should be assigned to all of these items, in line with the OECD methodology (see Appendix A.2.).

After calculation of the newest version of EPT sub-index and EPL index for Serbia (Version 3), we develop three adjusted indices, KEPL, KEPR and KEPRC. The methodology of calculation of adjusted indices is based on Berger et al. (2016), Jandric (2014), Boeri \& van Ours (2008), Rutkowski \& Scarpetta (2005) and Eamets \& Paas (2007a). The adjusted indices reflect both de iure strictness of EPL (i.e., the legal strictness of regulations) and its coverage. If de iure strictness is high, but the coverage is low, then de facto strictness of labour regulation is low. For total EPL index, the measure of coverage is informality - the higher informal sector is, the lower effective coverage of labour regulation will be, and de facto EPL strictness is lower, which will be reflected in the lower values of adjusted EPL index (i.e. KEPL).

The adjusted KEPL index represents EPL index which has been modified by the shadow economy share in GDP (which is denoted as SHE in equations (1) - (3)).

$$
K E P L=E P L *(1-S H E)
$$

The shadow economy and informal labour markets are "closely connected" (Fialova \& Schneider, 2014). Informality is more frequent in emerging countries where it is "mostly associated with sub-standard labour conditions", but it is also an important concern for more advanced economies (Di Porto, Elia, \& Tealdi, 2017). Theoretically, if the share of the shadow economy is zero, KEPL will equal EPL. The higher the share of the shadow economy, the difference between KEPL and EPL will be larger. If SHE is $100 \%$, KEPL index will be 
zero, which would point to infinite external numerical labour market flexibility (no regulation would be implemented in practice).

If regulation for regular contracts is too strict, firms may start to rely more on the temporary contract. If the share of employees with temporary contracts is high, the coverage of labour regulation for regular contracts is lower. In the calculation of the EPL index, the weight of EPR component is high. However, if the effective coverage of this part of labour regulation is low, then de facto strictness is also lower. Adjusted EPR and EPRC indices (i.e., KEPR and KEPRC) show de iure strictness of this part of labour regulation adjusted by the coverage of this regulation. If informality is high and/or the share of employees with standard contracts is low, then the de facto strictness of EPR and EPRC will be lower, and KEPR and KEPRC indices will also have lower values.

The adjusted EPR and EPRC indices take into account both the size of the informal sector and the share of employees with regular contracts in a total number of employed persons. The modified KEPR index is calculated when the standard EPR index is multiplied by the share of employees with the regular contracts in total employment and then by the share of the shadow economy. A lower share of employees with permanent contracts in total employment will reduce KEPR and KEPRC indices in comparison to their original values, and therefore indicate higher flexibility.

$$
\begin{aligned}
K E P R & =E P R * P C E *(1-S H E) \\
K E P R C & =E P R C * P C E *(1-S H E)
\end{aligned}
$$

PCE - share of employees with permanent contracts in total employment (age group 15+, 2017). Data are obtained from Labour Force Survey for Serbia and Eurostat database for other countries.

SHE - estimate of the share of the shadow economy in GDP. Data on shadow economy are based on Krstic et al. (2013) for Serbia and Schneider (2016) for other countries.

The EPL index, as well as EPR, EPRC, EPC and EPT sub-indices refer to de iure flexibility of the labour market. The modified KEPL, KEPR and KEPRC indices represent the approximation of the de facto situation, bearing in mind that adjusted indices, to a certain extent, take into account the implementation of the legal norms. The difference between the original and modified EPL indices should represent the difference between de iure and de facto conditions.

\section{Results and Discussion}

\subsection{Cross-country comparison of employment protection legislation according to unadjusted indices}

In the first step, we calculate the EPT sub-index for Serbia, which allows us to compute the total EPL index. EPT sub-index has two components: EPFTC, which refers to regulation on fixed-term contracts and EPTWA which shows the rigidity of the legal framework that regulates temporary agency work. In order to assign numerical scores necessary to calculate the EPFTC sub-index, we have answered the questions 1-3 in Table 2 on the basis of the Labour Law of the Republic of Serbia ("Official Gazette of the Republic of Serbia", no. 24/2005, 61/2005, 54/2009, 32/2013, 75/2014, 13/2017 - decision of the Constitutional Court and 113/2017), Article 37.

The European Directive on Temporary Agency Work (European Union, 2008; Directive 2008/104/EC) lays down the principles of non-discrimination and equal treatment, specifying general rules regarding working conditions of temporary agency workers, but the legal framework of Republic of Serbia is still not completely in line with the EU legislation (Krivokapic \& Mesanovic, 2016). The Labour Law does not regulate temporary agency work, and the law that should cover this area is still in preparation. While there are provisions that regulate establishing and functioning of employment placement agencies (with main activity being an intermediary between labour demand and supply), the temporary agency work in the current legal environment exists, but the rules that regulate it more closely are still not defined.

Therefore, in line with the current legal provisions, in all the questions related to TWA, the most flexible solutions were taken into the calculation of the EPTWA sub-index, which is consistent with the functioning of TWA in practice. 
With the obtained numerical scores for EPFTC and EPTWA and the weights given in the OECD methodology of the EPL computation, the value of EPT in Serbia is 2.04. Details on the methodology of assigning numerical scores and the weighting system are presented in Appendix (A.2. and A.3).

With the values of EPR and EPC given in the OECD database (Table 3), and the weights defined by the OECD (OECD, 2013):

$E P L=7 / 12^{\star} E P R C+5 / 12^{*} E P T$, the final value of the total EPL index for Serbia is 2.15.

Table 3: EPL and its subcomponents - values for Serbia, 2015-2018

\begin{tabular}{|l|l|l|}
\hline \multirow{3}{*}{ EPL: $\underline{2.15}$} & EPRC (7/12): 2.23 & EPR: 1.67 \\
\cline { 3 - 3 } & & EPC: 3.63 \\
\cline { 2 - 3 } & EPT (5/12): $\underline{2.04}$ & \\
\hline
\end{tabular}

Source: http://www.oecd.org/employment/emp/EPL-data.xlsx and author`s calculations

Figures 2-4 show the latest values of official indices and sub-indices in a chosen group of 26 European countries. The values of the indices for Serbia are below the average for the selected group of countries for total EPL index, as well for sub-indices EPR, EPRC and EPT. This means that employment protection legislation is less rigid than the average for this group of countries. The only exception is the EPC sub-index, which refers only to additional requirements in case of collective dismissals.

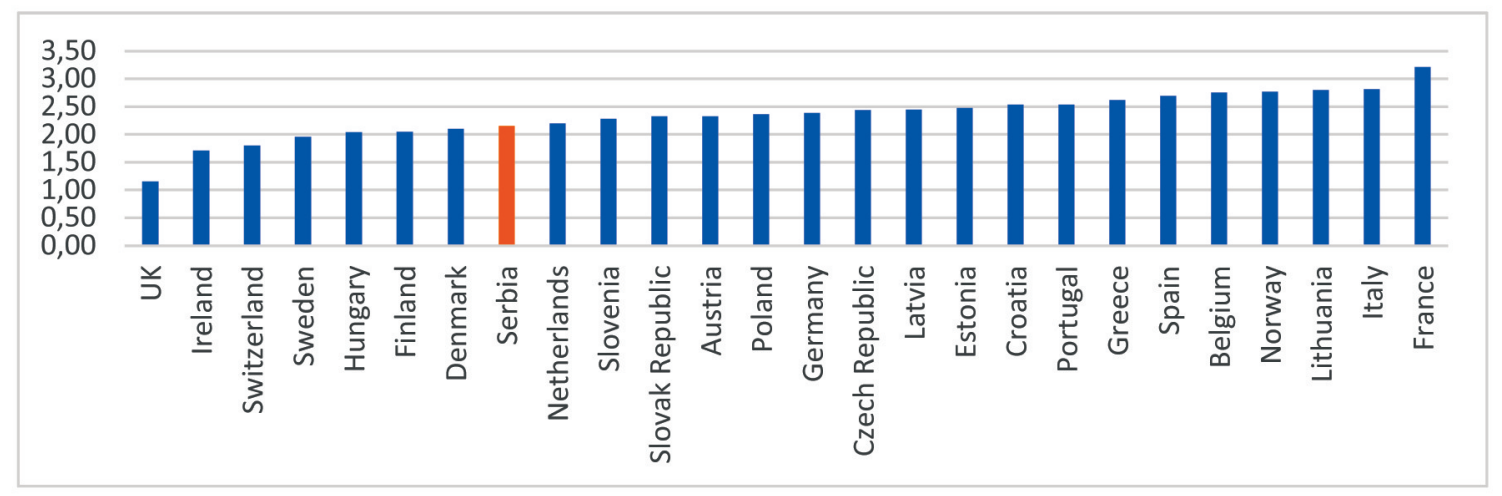

Figure 2: EPL index

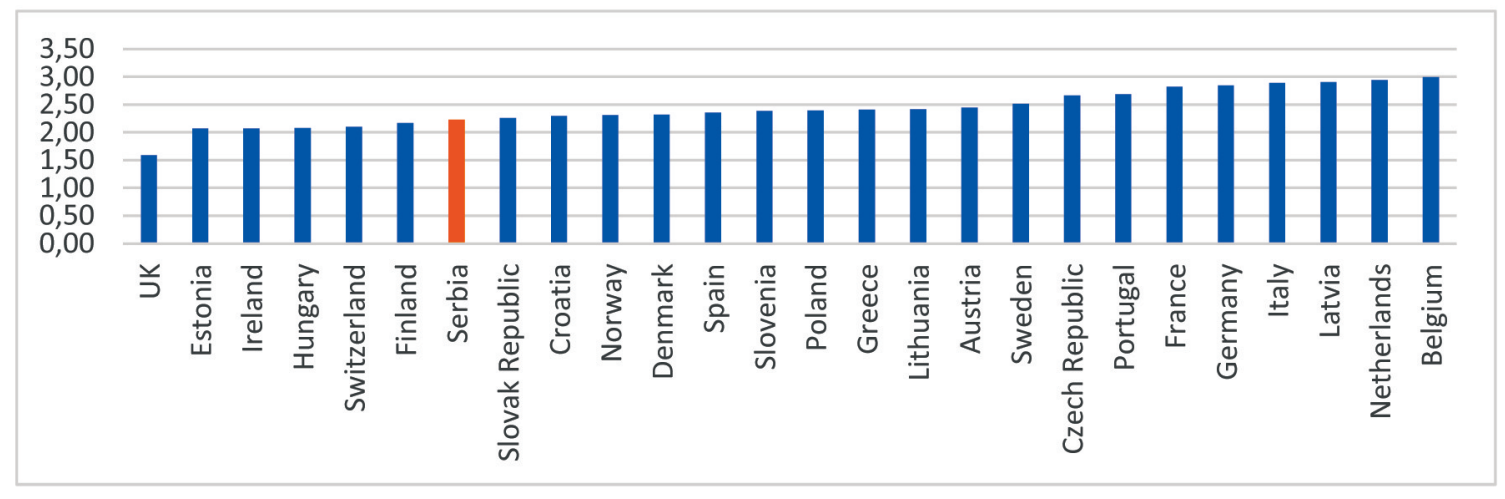

Figure 3: EPRC index 


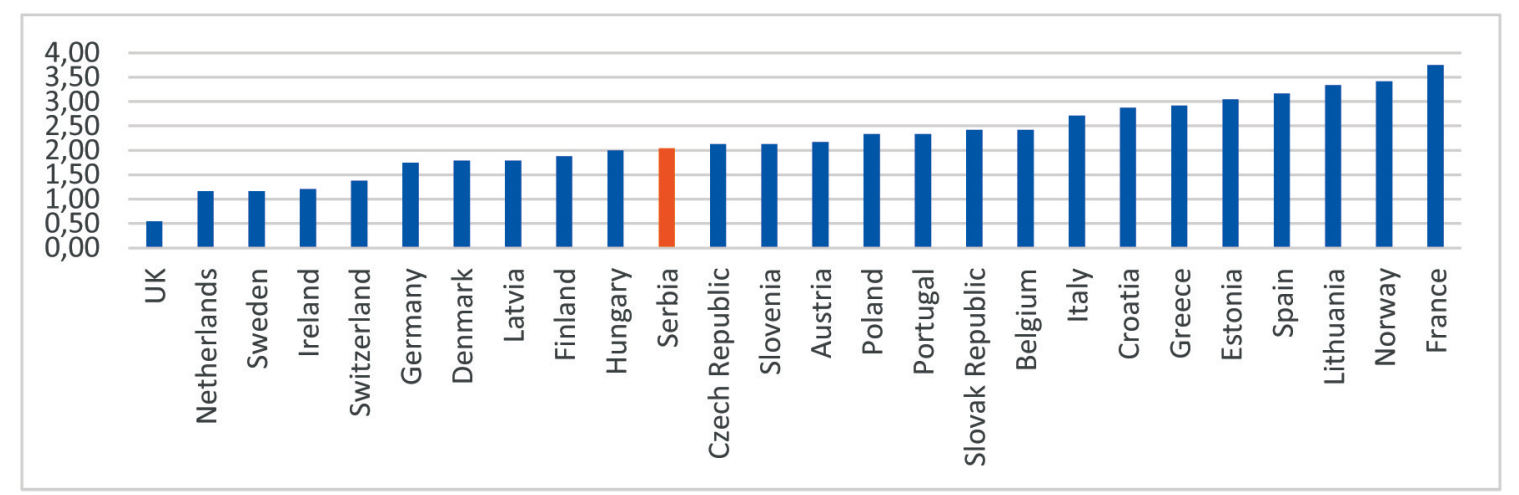

Figure 4: EPT index

\subsection{Relative position of Serbia based on adjusted EPL indices}

If we take into consideration the share of the employed with permanent contracts and estimated share of the shadow economy in the GDP, the ranking position of certain countries regarding the strictness of EPL changes significantly. The assumption is that in the countries with a higher share of the shadow economy in GDP, the share of employed who are not covered by the employment protection legislation provisions is proportionally higher, as well as the general degree of non-compliance with the legal norms. Modification of EPR and EPRC indices takes also into account the share of employed with standard contracts in total employment, who the regulation concerning EPR and EPRC indices refers to.

The difference between the original and modified indices, which is a consequence of taking into account the shadow economy, is in negative correlation with the value of the indicator of the World Economic Forum The protection of the property rights. This indicator is used as the approximate measure of (dis)respect of the law in a given country, while higher values point at the greater respect of property rights. It should be noted that there is a negative correlation between the values of this indicator and the share of the shadow economy in GDP (Pearson's coefficient of the correlation is -0.798). On average, in countries with higher perception of protection of property rights, the share of the shadow economy is smaller, as well as the difference between original and modified EPL index.

Figure 5 shows changes in the rankings of individual countries when KEPL is observed instead of EPL, while Figures 6 and 7 show changes in ranking when KEPR and KERRC are used instead of EPR and EPRC. The height of the column does not indicate the rigidity or flexibility of the labour market. It points only to the changes in rankings. i.e., to the change in a position relative to the other countries, when the adjusted indicator is taken into account. A lower rank indicates a higher flexibility. Therefore, negative values (rankKEPL < rankEPL) mean that the ranking based on the adjusted indices is lower than with the original ones. In that case, a relative de facto flexibility (compared to other countries) is higher than the relative de iure flexibility measured by original indices. Differences in rankings based on the original and adjusted EPL index arise from the fact that in countries with high share of the grey economy, regulations are more often disregarded, which artificially reduces the prescribed legal protection of employment.

Country rankings based on standard and adjusted indices do not vary greatly on average: the correlation coefficient between ranks based on EPL and KEPL indices is 0.82 . Similarly, the correlation coefficient of country rankings based on EPRC and KEPRC is 0.67 and 0.83 between EPR and KEPR rankings. Venn (2009) has shown that, in the group of all OECD countries, the ranking of countries is insensitive to weight changes in the calculation of the index, as well as to the introduction of weights based on the share of employees with temporary and fixed-term contracts (the coefficient of correlation for the standard EPL index and EPL index weighted by the structure of employees with different types of contracts is 0.95; Venn, 2009, p. 13). However, as shown in Figure 5, in a number of countries there are major changes in ranks. A significant change in the ranking towards greater flexibility compared to other countries, based on differences between EPL and KEPL, is present in Estonia, Lithuania, Croatia, Greece, Latvia and Serbia. A significant difference in rank is defined as a difference greater than 3 in absolute terms. 


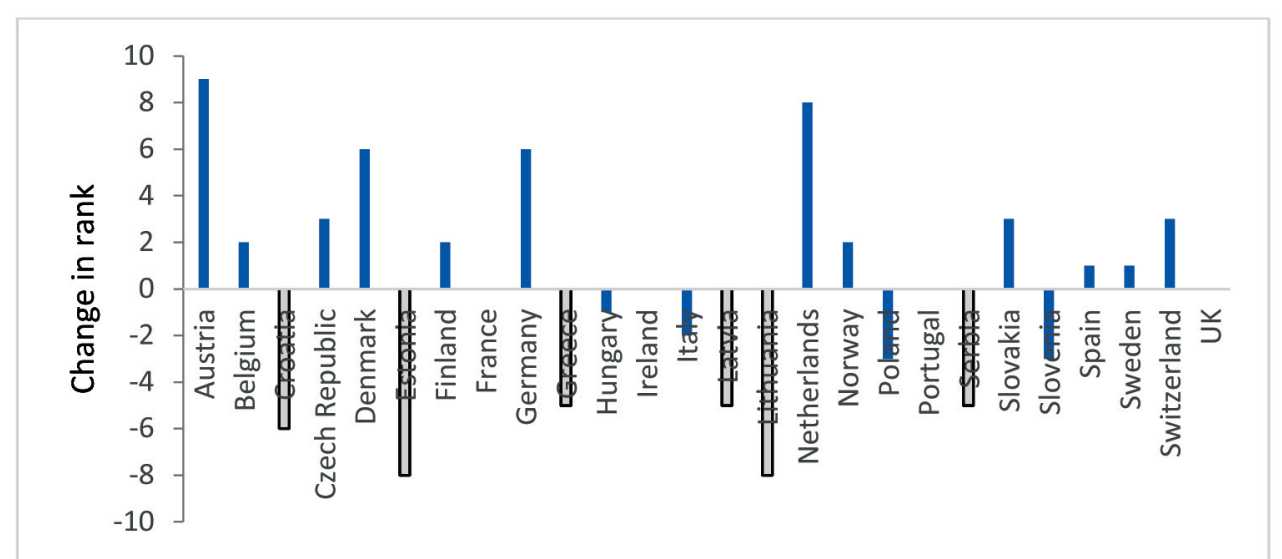

Figure 5: Changes in the rank after the introduction of the KEPL index*

*Negative values indicate that relative de facto flexibility is higher than the relative de iure flexibility.

Differences in rankings that occurred after adjusting the EPR and EPRC indices, besides the shares of the grey economy, also stem from the structure of employment. EPR and EPRC indices have a large influence on the final EPL index, due to the weighting system proposed by OECD. However, if the proportion of workers that are subject to these regulations (i.e., workers with permanent contracts) is small, the real influence of EPR on labour market rigidity is much weaker. Therefore, we have adjusted EPR and EPRC indices by the share of workers with unlimited contracts in the total employment. With the adjusted EPR and EPRC indices, countries with a smaller share of workers with permanent contracts have lower adjusted indices, which points to larger de facto flexibility in comparison to other countries.

Table 4: Countries with greater de facto relative flexibility

\begin{tabular}{|l|l|}
\hline $\begin{array}{l}\text { Countries with de facto higher flexibility } \\
\text { according to KEPRC (difference in ranking }>3 \\
\text { in absolute terms) }\end{array}$ & $\begin{array}{l}\text { Countries with de facto higher flexibility } \\
\text { according to KEPR (difference in ranking }>3 \\
\text { in absolute terms) }\end{array}$ \\
\hline $\begin{array}{l}\text { Poland, Greece, Italy, Portugal, Serbia, Spain, } \\
\text { Slovenia, Croatia, Netherlands }\end{array}$ & Poland, Italy, Greece, Portugal, Croatia, Serbia \\
\hline
\end{tabular}

Source: authors`calculation

In the context of international comparisons, the real rigidity of the employment protection legislation in Serbia is lower than when viewed only on the basis of original indices which are based on legal regulations. In recent years, indicators that reflect the state of the regulation show a move towards greater flexibility - the value of the EPL index has decreased in comparison with the beginning of 2014. The amendments to the Labour Law of 2014 were to a large extent aimed at reducing the rigidity of employment protection legislation, which resulted in a decrease in the value of this index. In addition, the so-called "hidden rigidities", which did not affect the value of the EPL index, but in practice represented additional restrictions for the dismissal of employees, were removed. One example is the method of calculating redundancy payments, which was the source of the highest number of criticisms of the old legal solutions with arguments that in this way the potential discrimination of employment of persons with many years of work experience was encouraged (Arandarenko, 2011b).

Table 5: EPL changes in Serbia 2014-2015

\begin{tabular}{|c|c|c|c|c|}
\hline Serbia & EPRC & EPR & EPT & EPL \\
\hline 2014 (before the Labour Law changes) & $2.28^{*}$ & $1.89 *$ & $2.29 *$ & $2.28^{\star}$ \\
\hline 2015- & $2.23^{\star *}$ & $1.67^{\star \star}$ & $2.04 * * \star$ & $2.15^{\star \star *}$ \\
\hline
\end{tabular}

A valuable indicator of subjective perception of employment protection legislation rigidity is Hiring and firing practices issued by the World Economic Forum. This indicator is part of the Global Competitiveness Report and it refers to the question: "In your country, to what extent do regulations allow flexible hiring and firing of 
workers?". Unlike the EPL, EPR, EPRC and EPT indices that are calculated on the basis of the existing legal regulations, the Hiring and firing practices indicator refers to the business executives' perception of the limitations for hiring and dismissing workers. A higher value of this indicator points to the higher perception of flexibility. There is a negative correlation between the value of Hiring and hiring practices indicator and both EPL and KEPL indices (correlation coefficient is -0.67 and -0.55 , respectively).

Even though adjusted indices show a higher de facto flexibility, Serbia takes the 80th place in the group of 137 countries according to the perceptions on hiring and firing difficulties. In the period 2007-2015, the ranking according to the indicator Hiring and firing practices was significantly worsened - from the 25th place in 2007, Serbia reached 115th in 2014/2015 report. However, there has been some improvement since then - in the following Global Competitiveness Reports (World Economic Forum 2015/2016 - 2017/2018; World Economic Forum, 2017), the ranking of Serbia has improved compared to 2014/2015. The indicator values declined until 2015/2016 (Figure 8), which means that the employers still perceive that the procedures related to the dismissal and employment of workers are more rigid in comparison with other countries, and even more so than in previous years. The improvement of the employers' perception of flexibility is visible in the last two years, which might be the result of the Labour Law changes in 2014. Another theoretical explanation in this regard is related to the possibility that court decisions may be dependent on the business cycle - according to Bertola, Boeri \& Cazes (2000, p: 18.): "judges may feel that workers should be more heavily protected against dismissals during cyclical downturns than in buoyant labour market conditions". In this context, perceptions of the strictness of regulations measured by WEF may reflect the court decisions, i.e., the effects of business cycle (Aleksynska \& Cazes, 2016, p. 15).

Figure 8: Value of the WEF indicator Hiring and firing practices, Serbia*

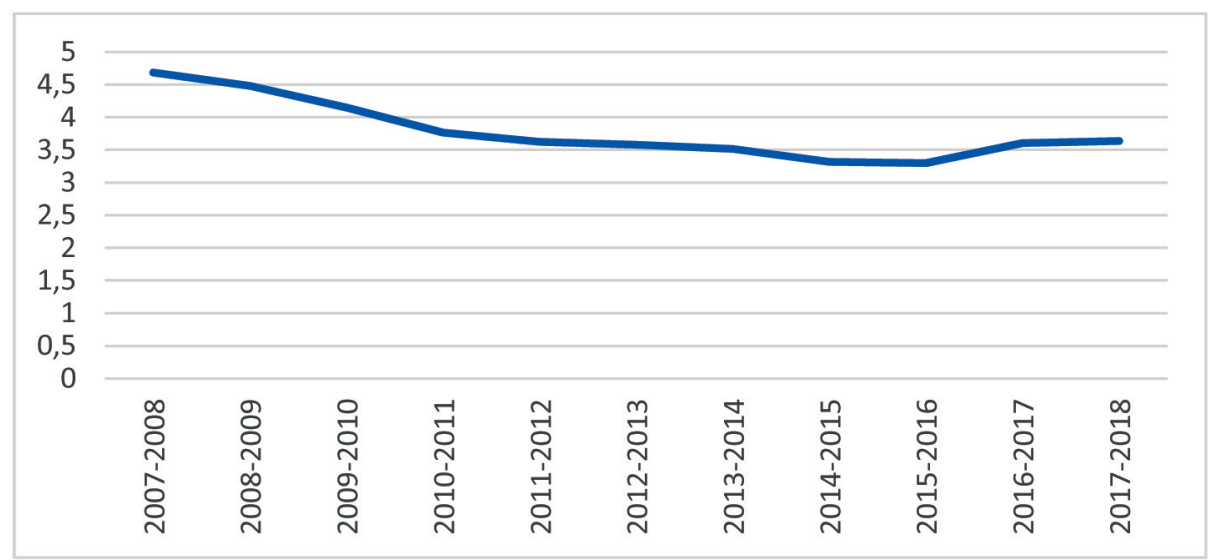

* related to the question in the Survey: "In your country, to what extent do regulations allow flexible hiring and firing of workers? [1 = not at all; 7 = to a great extent]"

\section{Conslusion}

The OECD's EPL Index is most commonly used for international comparisons of employment protection legislation. One of the shortcomings of this index stems from the fact that in countries with a significant share of the grey economy, the labour market flexibility is de facto higher than the index shows, since the legal provisions apply only to employees in the formal part of the economy. If the application of legal norms is inadequate, indicators based on legal regulations do not give a realistic picture of the employment protection legislation. Also, recent studies show that results of the empirical research focused on the economic consequences of labour regulation differ if indicators based on de facto situation are used instead of the usual, de iure indicators. However, studies that use de facto indicators are still very rare, since it is often hard to capture the level of the law enforcement. The calculation of adjusted indicators of EPL in this paper is based on the methodology originally developed in previous research conducted by Berger et al. (2016), Boeri \& van Ours (2008), Rutkowski \& Scarpetta (2005) and Eamets \& Paas (2007a), New indicators reflect both de iure strictness and the effective coverage of the EPL index, as well as of EPR and EPRC indices. After computation of EPT and EPL indices for Serbia, three adjusted indices have been developed in this paper: KEPL, KEPR and KEPRC. The adjusted EPL index is corrected by the share of the shadow economy in GDP, while the adjusted EPR and EPRC indices also take into account the share of workers with permanent contracts. The corrected KEPL, KEPR and KEPRC indices represent an approximation of the de facto employment protection legislation, since, apart from the employment structure, through the correction by the share of the grey economy, the occurrence of non-compliance with legal norms is also taken into account to a certain extent. A 
more significant change in the ranking towards greater flexibility (compared to other countries) based on the differences between EPL and KEPL is present in: Estonia, Lithuania, Croatia, Greece, Latvia and Serbia. On the other hand, the differences in the ranking achieved by adjusting the EPR and EPRC indices, are also derived from the structure of the employment. In all cases, in the context of international comparisons, the real flexibility of employment protection legislation in Serbia is higher than when viewed only on the basis of original indices which are based on legal regulations. Although labour market flexibility can bring benefits to labour market functioning, this type of easing employment protection legislation, obtained by the relatively high incidence of non-compliance with the legal norms (approximated by the share of shadow economy) is not an optimum way to gain more flexibility, since it is associated with high legal insecurity. The method presented in the paper is able to give information of the relative position of a country in terms of strictness of labour regulation. In order to get more accurate measures, more sophisticated methods should be used. Since literature on de facto measures of the EPL is still rather scarce, this is an important avenue for further research.

\section{REFERENCES}

[1] Aleksynska, M., \& Cazes, S. (2016). Composite indicators of labour market regulations in a comparative perspective. IZA Journal of Labor Economics, 5(3). DOI:10.1186/s40172-016-0043-y

[2] Aleksynska, M., \& Eberlein, F. (2016). Coverage of employment protection legislation. IZA Journal of Labor Policy, 5(1). DOI:10.1186/s40173-016-0073-x

[3] Almeida, R., \& Carneiro, P. (2012). Enforcement of labor regulation and informality. American Economic Journal: Applied Economics, 4(3), 64-89. DOI:10.1257/app.4.3.64

[4] Amine, S. (2015). Reflections On Employment Protection Legislation: An International Comparison. Comparative Economic Research, 18(1), 119-130. doi: 10.1515/cer-2015-0007

[5] Arandarenko, M. (2011a). Tržište rada u Srbiji - trendovi, institucije i politike. Beograd: Ekonomski fakultet Univerziteta u Beogradu.

[6] Arandarenko, M. (2011b). Pomoćne strategije za oporavak od krize u jugoistočnoj Evropi - Studija procene: Srbija. Budapest: ILO. Retrieved from: https://www.ilo.org/wcmsp5/groups/public/---europe/--ro-geneva/---sro-budapest/documents/publication/wcms_167015.pdf

[7] Arsic, M., Arandarenko, M., Radulovic, B., Randjelovic, S., \& Jankovic, I. (2015). Causes of the shadow economy. In G. Krstic \& F. Schneider (Eds.), Formalizing the shadow economy in Serbia - policy measures and growth effects (pp. 21-46). Springer. DOI: 10.1007/978-3-319-13437-6

[8] Berger, J., Biffl, G., Schuh, U., \& Strohner, L. (2016). Updating of the labour market model. Brussels: European Commission - Directorate-General for Employment Social Affairs and Inclusion. DOI: $10.2767 / 691738$

[9] Bertola, G., Boeri, T., \& Cazes, S. (2000). Employment protection in industrialized countries: The case for new indicators. International Labour Review, 139(1), 57-72. DOI: 10.1111/j.1564-913X.2000.tb00402.x

[10] Boeri, T. \& van Ours, J. (2008). The economics of Imperfect Labour Markets. New Jersey: Princeton University Press.

[11] Boeri, T., Helppie, B., \& Macis, M. (2008). Labor regulations in developing countries: A review of the evidence and directions for future research. World Bank Social Protection Discussion Paper 833. DOI: 10.1007/s00285-014-0778-7

[12] Caballero, R. J., Cowan, K. N., Engel, E. M. R. A., \& Micco, A. (2013). Effective labor regulation and microeconomic flexibility. Journal of Development Economics, 101, 92-104. doi: 10.1016/j.jdeveco.2012.08.009

[13] Calderon, C., Chong, A., \& Leon, G. (2007). Institutional enforcement, labor-market rigidities, and economic performance. Emerging Markets Review, 8(1), 38-49. DOI: 10.1016/j.ememar.2006.11.001

[14] Di Porto, E., Elia, L., \& Tealdi, C. (2017). Informal work in a flexible labour market. Oxford Economic Papers, 69(1), 143-164. DOI: 10.1093/oep/gpw010

[15] Djankov, S., \& Ramalho, R. (2009). Employment laws in developing countries. Journal of Comparative Economics, 37, 3-13. DOI: 10.1016/j.jce.2008.10.003

[16] Eamets, R., \& Paas, T. (2007a). Flexicurity: Combining Labour Market Flexibility and Security in the Baltic States. In H. Jørgensen \& P. K. Madsen (Eds.), Flexicurity and Beyond Finding a new agenda for the European Social Model (pp. 391-420). Copenhagen: DJOF Publishing.

[17] Eamets, R., \& Paas, T. (2007b). Labour Market Flexibility and Employment Security. In T. Paas \& R. Eamets (Eds.), Labour Market Flexibility, Flexicurity, and Employment: Lessons of the Baltic States ( $p$. 41-60.). New York: Nova Science Publishers, Inc.

[18] European Union (2008). Directive 2008/104/EC of the European Parliament and of the Council of 19 November 2008 on temporary agency employment, Official Journal of the European Union, L 327/9-14. Retrieved from: https://eur-lex.europa.eu/legal-content/en/ALL/?uri=CELEX\%3A32008L0104

[19] European Commission. (2016). Employment and Social Developments in Europe 2015. Brussels: European Commission - Directorate-General for Employment, Social Affairs and Inclusion. 
[20] Fialova, K., \& Schneider, O. (2014). Labor market institutions and their impact on shadow economies in Europe. Review of Economics and Institutions, 5(1), 1-40. DOI: 10.5202/rei.v5i1.146

[21] Florez, L., \& Perales, F. (2016). Labour Protection and Informal Work: A Cross-National Analysis of European Countries, 2004-2012. International Labour Review, 155(4), 623-650. DOI: 10.1111/j.1564913X.2015.00049.X

[22] Jandric, M. (2014). Doktorska disertacija. Fleksibilnost i sigurnost na tržištu rada i uticaj na nezaposlenost u zemljama u tranziciji. Ekonomski fakultet Univerziteta u Beogradu.

[23] Jandric, M., \& Savicevic, I. (2014). Pokazatelji fleksibilnosti tržišta rada: primer Srbije. In M. Jaksic \& M. Arandarenko (Eds.), Reforme i razvoj: stanje, rezultati i početak pregovora Srbije sa EU (p. 151-164.). Beograd: Ekonomski fakultet u Beogradu.

[24] Kanbur, R., \& Ronconi, L. (2018). Enforcement matters: The effective regulation of labour. International Labour Review, 157(3), 331-356.

[25] Krivokapic, D., \& Mesanovic, E. (2016). Radnici na lizing - Vodič o pravima radnika privremeno angažovanih preko agencija za zapošljavanje. Beograd: Share Fondacija i Međunarodni centar Olof Palme.

[26] Krstic, G., Schneider, F., Arandarenko, M., Arsic, M., Radulovic, B., Randjelovic, S., \& Jankovic, I. (2013). Siva ekonomija u Srbiji: novi nalazi i preporuke za reforme. Beograd: Fond za razvoj ekonomske nauke, USAID.

[27] Labour Law of the Republic of Serbia ("Official Gazette of the Republic of Serbia", no. 24/2005, 61/2005, 54/2009, 32/2013, 75/2014, 13/2017 - decision of the Constitutional Court and 113/2017)

[28] Myant, M., \& Brandhuber, L. (2016). Uses and Abuses of the OECD's Employment Protection Legislation Index in Research and EU Policy Making. Working paper series of Economic, Employment and Social Policies at the European Trade Union Institute (ETUI), Brussels, 2016.11.

[29] OECD. (2013). Employment Outlook 2013. OECD Publishing. DOI:10.1787/empl_outlook-2013-en

[30] OECD. (2014). Calculating summary indicators of EPL strictness: methodology. Retrieved from: https://www.oecd.org/els/emp/EPL-Methodology.pdf

[31] Prosser, T. (2016). Dualization or liberalization? Investigating precarious work in eight European countries. Work, Employment and Society, 30(6), 949-965. DOI: 10.1177/0950017015609036

[32] Quinlan, M., \& Sheldon, P. (2011). The Enforcement of Minimum Labour Standards in an Era of NeoLiberal Globalisation: An Overview. The Economic and Labour Relations Review, 22(2), 5-32. DOI: $10.1177 / 103530461102200202$

[33] Rutkowski, J., \& Scarpetta, S. (2005). Enhancing job opportunities: Eastern Europe and the former Soviet Union. Washington DC: The World Bank.

[34] Schneider, F. (2016). Estimating the Size of the Shadow Economies of Highly-Developed Countries: Selected New Results. CESifo DICE Report (Vol. 14).

[35] Schneider, F., \& Klinglmair, R. (2004). Shadow economies around the world: what do we know? Working Papers of Johannes Kepler University of Linz, Department of Economics No. 0403

[36] Ulyssea, G. (2010). Regulation of entry, labor market institutions and the informal sector. Journal of Development Economics, 91(1), 87-99. DOI: 10.1016/j.jdeveco.2009.07.001

[37] Venn, D. (2009). Legislation, Collective Bargaining and Enforcement: Updating the OECD Employment Protection Indicators. OECD Social, Employment and Migration Working Paper No. 89. Retrieved from: www.oecd.org/els/workingpapers

[38] Verkerke, J. H. \&, Benoit, F. (2017), Mapping Employment Dismissal Law: A Leximetric Investigation of EPL Stringency and Regulatory Style. DOI: 10.2139/ssrn.2989848

[39] World Bank. (2012). World Development Reprt 2013: Jobs. Washington DC: The World Bank

[40] World Bank. (2018). World Development Report 2019: The Cnaging Nature of Work. Washington DC: The World Bank

[41] World Economic Forum. (2017). The Global Competitiveness Report 2017-2018. Retrieved from: http://www3.weforum.org/docs/GCR20172018/05FullReport/TheGlobalCompetitivenessReport2017\%E2\%80\%932018.pdf

Received: 2018-10-22

Revisions requested: 2018-12-16

Revised: 2018-05-13 (2 times)

Accepted: 2019-05-22 


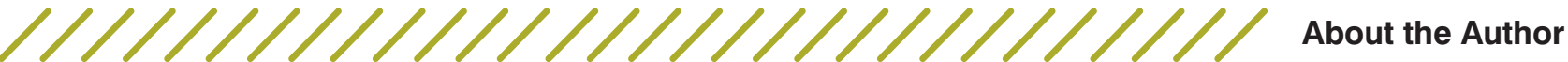

\author{
Maja Jandrić \\ University of Belgrade, Faculty of Economics, Serbia \\ e-mail:majasj@gmail.com
}

Maja Jandrić is assistant professor at the Faculty of Economics, University of Belgrade, where she teaches courses in Basic Macroeconomics and Theory and Analysis of Economic Policy. She received her B.A., M.A. and Ph.D. degrees from the same faculty. Her main field of expertise is concerned with macroeconomic analysis, economic policy and specifically labour market issues, with focus on flexibility and security issues in the labour market. Maja Jandrić authored a large number of publications and took part in a number of scientific and professional conferences in the country and abroad. She has also participated in a number of significant domestic and international scientific projects.

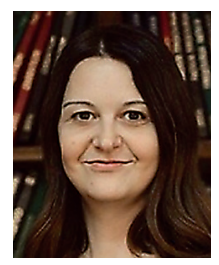

\section{Appendix A.1.}

EPL index has two sub-components: 1) EPRC, which contains EPR and EPC sub-indices and 2) EPT subindex.

EPR, the sub-index which refers to the individual dismissals of the workers with regular contracts, includes several aspects of employment protection: procedural inconveniences encountered by the employer when the dismissal process commences, such as notification procedures and the requests in connection to the consulting with the third parties; notice periods and severance payments; consequences for the employer in case it is established that the dismissal was unfair; length of trial period, etc.

Additional limitations to collective dismissals are shown through the EPC sub-index. These limitations refer to the fact that most countries specify additional costs and procedures when dismissing a larger number of employees at the same time. This measure includes just the additional costs related to the collective dismissals and it does not reflect the total strictness of the regulation about the collective dismissals, which is the sum of both costs, those of the individual dismissals and the additional ones that only refer to collective dismissals.

EPR and EPC both measure the strictness of regulation for regular contracts. EPRC sub-index encompasses these two indicators and cover regulation for individual and collective dismissals for workers with permanent contracts.

Regulation of the temporary forms of employment is shown by the EPT sub-index and refers to the employees with fixed-term contracts (FTC) and temporary agency work (TWA). EPT covers the issues such as: cases when these contracts are permitted, the maximum duration of these types of contracts and additional requirements for temporary agency work. The total EPL index is the weighted average of EPRC and EPT sub-indices, with the weights defined by the OECD methodology.

There are three versions of the total EPL index:

- Version 1: does not contain the sub-indicator EPC (data available since 1985)

- Version 2: contains the sub-indicator EPC (data available since 1998)

- Version 3: contains the sub-indicator EPC, and in comparison with Version 2, there are three more additional items, based on which newer versions of sub-indices EPT and EPR can be obtained (data available since 2008). 
Appendix A.2. Temporary employment - assigning numerical scores for calculation of EPT

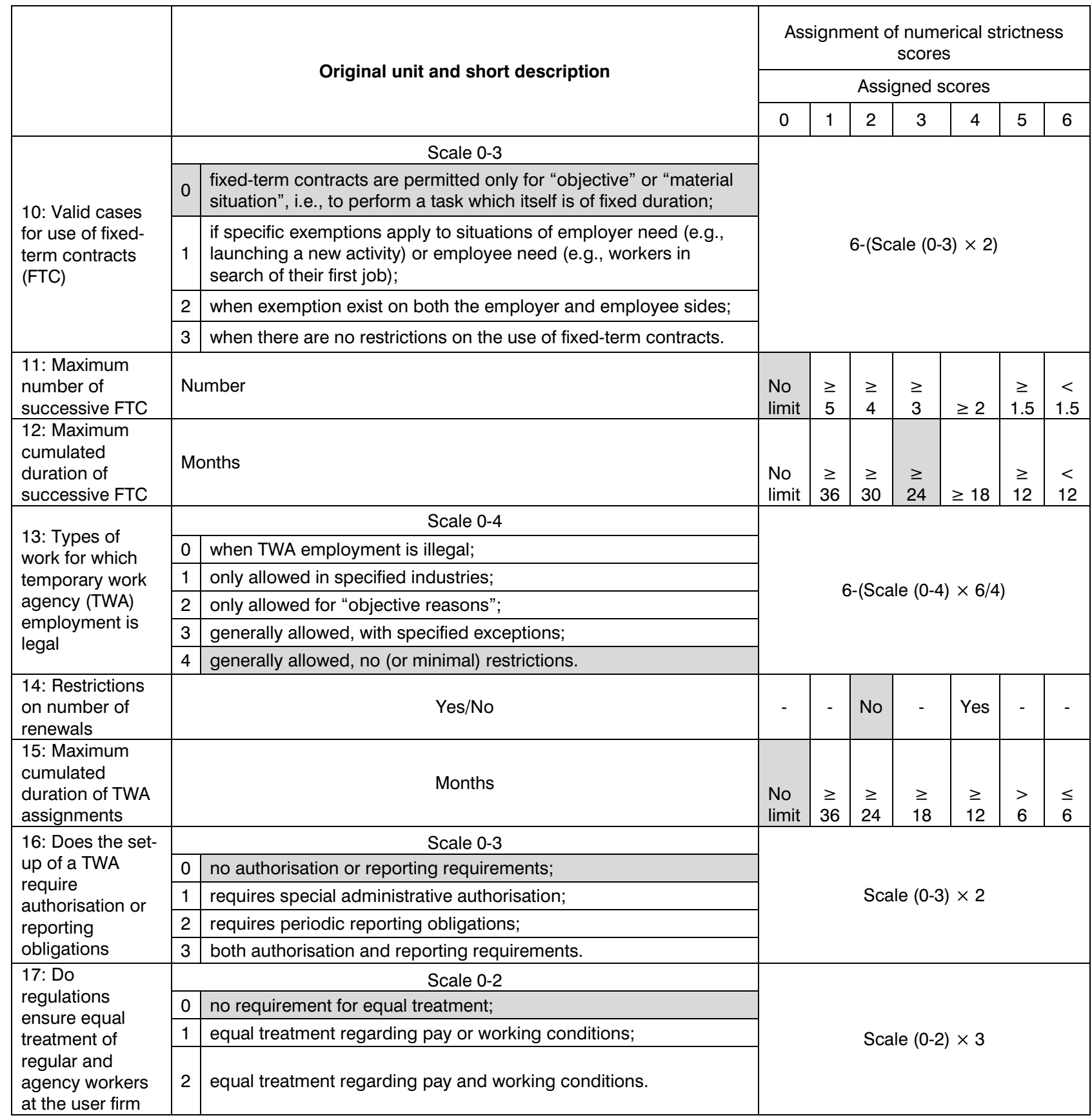

Source: OECD (2014) 
Appendix A.3. Strictness of employment protection - temporary contracts, summary indicator weights

\begin{tabular}{|c|c|c|c|}
\hline $\begin{array}{c}\text { Level } 1 \text { \& } 2 \\
\text { Scale 0-6 }\end{array}$ & $\begin{array}{l}\text { Level } 3 \\
\text { Scale 0-6 }\end{array}$ & $\begin{array}{c}\text { Level } 4 \\
\text { Scale 0-6 }\end{array}$ & $\begin{array}{c}\text { Version } 3 \\
\text { weights }\end{array}$ \\
\hline \multirow{8}{*}{$\begin{array}{l}\text { Temporary } \\
\text { contracts } \\
(\mathrm{EPT})\end{array}$} & \multirow{3}{*}{$\begin{array}{l}\text { Fixed term } \\
\text { contracts (EPFTC) } \\
(1 / 2)\end{array}$} & 10. Valid cases for use of fixed-term contracts & $(1 / 2)$ \\
\hline & & 11. Maximum number of successive contracts & $(1 / 4)$ \\
\hline & & 12. Maximum cumulated duration & $(1 / 4)$ \\
\hline & \multirow{5}{*}{$\begin{array}{l}\text { Temporary work } \\
\text { agency } \\
\text { employment } \\
\text { (EPTWA) } \\
(1 / 2)\end{array}$} & 13. Types of work for which is legal & $(1 / 3)$ \\
\hline & & 14. Restrictions on number of renewals & $(1 / 6)$ \\
\hline & & 15. Maximum cumulated duration & $(1 / 6)$ \\
\hline & & 16. Authorisation and reporting & $(1 / 6)$ \\
\hline & & 17. Equal treatment & $(1 / 6)$ \\
\hline
\end{tabular}

Source: OECD (2014) 